\title{
Molecular Phylogeny of Polyporales from Bafut Forest, Cameroon and Their Importance to Rural Communities
}

\author{
Tonjock Rosemary Kinge (Corresponding author) \\ Department of Biological Sciences, Faculty of Science, The University of Bamenda, P.O. \\ Box 39, Bambili, North West Region, Cameroon \\ Email: rosemary32us@yahoo.com \\ Azinue Clementine Lem \\ Department of Biological Sciences, Faculty of Science, The University of Bamenda, P.O. \\ Box 39, Bambili, North West Region, Cameroon \\ Email: azinuelem6@gmail.com \\ Seino Richard Akwanjoh \\ Department of Biological Sciences, Faculty of Science, The University of Bamenda, P.O. \\ Box 39, Bambili, North West Region, Cameroon \\ Email: raseino@yahoo.co.uk
}

Received: January 9, 2019 Accepted: January 26, 2019

doi:10.5296/jbls.v10i2.14339 URL: https://doi.org/10.5296/jbls.v10i2.14339

\begin{abstract}
The polyporales are a large order of pore fungi within the Basidiomycota (Kingdom Fungi). They are mostly found on decay wood with some edible and medicinal species and others causing diseases of trees. In Cameroon, the knowledge on the phylogeny of polyporales is limited, their historical uses as food, medicine, source of income and the sociological impacts are apparently threatened due to slow ethnomycology research drive. The aim of this study was to identify and determine the phylogenetic relationship of polyporales in the Bafut forest and document its uses to the local communities. DNA was extracted using CTAB method and amplified using primers ITS 1 and ITS4. Their identities were determined in GeneBank using BLAST and a phylogenetic analysis was done using MEGA version 7. For ethnomycological studies, a total of 180 semi structured questionnaires were used to collect information on traditional knowledge in four communities around the Bafut forest. Results from phylogenetic studies showed that, ten species were identified and belonged to seven genera comprising of the Microporus, Hexagonia, Ganoderma, Trametes, Favolus, Steccherinum and
\end{abstract}


Cymatoderma which formed 7 independent monophyletic groups. Ethnomycological findings revealed that, polypores are used as food and medicine within these communities. Microporus xanthopus and Microporus vernicipes were used as food and medicine while all Trametes species were reported to be only medicinal. The Bafut people commonly called mushrooms "Boh" and those that grow on wood "Boh ti". They usually differentiate the edible and nonedible mushroom using the term "yi kworu" and "yi tekworu". Thus "Boh yi kworu" and "Boh yi tekworu" respectively. This study represents the first on the identification, phylogeny and uses of polyporales to the communities around the Bafut forest reserves and helps in their conservation.

Keywords: identification, phylogeny, polyporales, traditional knowledge

\section{Introduction}

The Polyporales are an order of about 1800 species of fungi in the division Basidiomycota. They are commonly called Polypores, which are an important polyphyletic group of wood decaying basidiomycetes fungi with poroid hymenophores (Hibbett et al., 2007), and woody fruiting bodies called conks (Kirk et al., 2008). The order includes some (but not all) polypores as well as many corticioid fungi and a few agarics (mainly in the genus Lentinus). They have several uses with respect to their medicinal, nutritional, economic and ecological potentials. For examples, First century Greek physician Dioscorides, included the lurch polypore, (Fomitopsis officinalis, Laricifomes officinalis in his De Materia medica known then as Agaricum and later as the Quinine conk was used for the treatment of tuberculosis. Some of the polypores are cultivated for commercial purposes and are edible for example, Laetiporus sulphureus. Polypores are also among the most efficient decomposers of lignin and cellulose, the main components of wood thus recycling a major part of nutrients in forests (Li \& Cui, 2013).

In Cameroon, polyporales have been studied in several regions either as a group such as Douanla-Meli (2007) who studied the ecological diversity of mushrooms from the Mbalmayo forest reserves with emphasis on the taxonomy of non-gilled Hymenomycetes. Two hundred and seventy one distinct species of polypores were recorded belonging to 110 genera in 58 families. Many new records and species new to science, and important ethnomycological notes for people in and around the Mbalmayo forest reserves were documented. Roberts \& Ryvarden (2006), reported over 70 poroid species from the Korup rainforest, Cameroon. Poroid bracket fungi were found to be among the most prominent of forest fungi, often producing large, perennially visible fruiting bodies. Also, the poroid bracket fungi are ecologically important as the main decomposers of dead and fallen wood forming an essential part of the forest nutrient recycling system and many medicinal mushrooms. One genus and 16 species new to science were described. Nunez \& Daniels (1999), studied fungi from the Dja Biosphere reserve and found 23 species of polypores new to Cameroon. Species of Amauroderma, Ganoderma, Phellinus, Antrodiella and Coriolopsis were found among others. Genus wise or together with macrofungi, polypores has been studied in Cameroon. For example; the works of Kinge \& Mih (2015), who worked on diversity and distribution of species of Ganoderma in south western Cameroon, the work of Kinge et al. (2013) on the first 
checklist of macrofungi in the mount Cameroon region. Also, Teke et al. (2017) on macro fungal diversity in the Kilum Ijim forest, North West region of Cameroon in which polypores were identified together with other macrofungi.

Most polypores inhabit tree trunks or branches consuming the wood, but some are soil-inhabiting species and form mycorrhiza with trees. Over one thousand polypore species have been described to science (Kirk et al., 2008). Some described species include; Ganoderma lucidum, Trametes versicolor, Laetiporus sulphureus and Fomitopsis pinicola, these species differ from each order by shape of the basidiocarp, pore size, colour, thickness, however, species such as Lenzites betulina, Gloeophyllum sepiarium possess gills on their under surfaces. Polypores are much more diversed in old natural forests with abundant dead wood than in younger managed forests or plantations. Consequently, a number of species have declined drastically and are under threat of extinction due to logging and deforestation (Kirk et al., 2008). Only Basidiomycetes are known to initiate lignin degradation (cause white rot) (Nakasone, 2013). Polyporous fungi are used in forest management planning as indicators of stands valuable for conservation (Aandra et al., 1996).

The taxonomy of fungi has traditionally been based on the morphological features of the basidiocarps. Identification based on these basidiocarp features, however, is prone to problems such as absence of basidiocarp during certain time of the year, their morphological plasticity and presence of cryptic species (Moncalvo \& Ryvarden, 1997; Gottlieb \& Wright, 1999). For these reasons, contemporary taxonomy and identification of fungal species employ morphological studies and DNA sequence information. The ITS1-5.8S-ITS2 rDNA is a hyper variable region, that is, this region reflects more variation than either the $18 \mathrm{~S}$ or the 25-28S rDNA. The evolutionary distance resolved by the ITS is usually restricted to demarcating within the species level and cannot be completely relied above genus level, like $18 \mathrm{~S}$ or $25-28 \mathrm{~S}$ rDNA. Organisms showing more than $90 \%$ similarity can be considered as belonging to the same genus. Whereas for $18 \mathrm{~S}$ rDNA sequence homology, $\geq 90 \%$ sequence identity can safely be considered as belonging to the same genus (Guarro et al., 1999). Currently the taxonomy of polypores is primarily based on morphological characteristics, such as the shapes of basidiocarps and hymenophores, hyphal systems, and forms and sizes of basidiospores, and secondarily on mycological features like host relationship and rot types (brown versus white) (Ryvarden, 1991). However, overlapping and variable morphological characteristics have made the classification of polypores unreliable and unstable, which has always been a nuisance to mycologists (Alexopoulos et al., 1996; Hibbett \& Donoghue, 1995).

Polypores, have several ecological functions in both natural and agro ecosystems, and are widely exploited by humans for food and medicine (Mueller et al., 2007; Osemwegie et al., 2006). Some of the Polyporales are reported to be edible as food and also used in ethnomedicine. For example, Lentinus squarrosulus Mont. (Syn. Lentinus subnudus Berk.) is a highly prized Nigerian mushroom, which is appreciated for its meaty taste and texture (Kadiri, 2005). Moreover, the L. squarrosulus fruit bodies are rich in ascorbic acid and amino acids, and protein in their most abundant nutrient (Fasidi \& Kadiri, 1990). Apart from the use as food, the polyporales are also commercially cultivated for medicinal purposes especially in 
traditional Chinese medicine that is; Ganoderma lucidum (Curtis) P. Karst (ling-zhi), Grifola frondosa (Dicks.) Gray (maitake) and Trametes versicolor (L.) Lloyd (yun-zhi). Ganoderma is commonly used for pharmaceutical purposes and as health foods (Chang, 1996). Traditionally, it is prepared into various formulations for external use (Wachtel et al., 2011). Ganoderma lucidum is believed to have maximum number of therapeutic properties (Barbosa-Filho et al., 2006) and a large number of experimental evidences provide scientific support to many of the ancient claims of its health benefits; for this reason, G. lucidum has been included in the American herbal pharmacopoeia and therapeutic compendium (Chen et al., 2012). Majority of these medicinal properties are related to the antitumor, antioxidant and antimicrobial potentials (Jia et al., 2009). Despite the studies of polypores and together with other mushrooms in Cameroon, polypores specific studies on identification, phylogeny and their uses to the local communities has not been carried out in many habitat types and in the Bafut forest and communities in particular. The aim of this study was to identify polypores present in the Bafut forest, determine their phylogenetic relationship and the importance of these polypores to the local communities.

\section{Materials and Methods}

\subsection{Description of Site}

The Bafut forest is located north of Mezam Division, North West Region of Cameroon. The study area ranges from Latitude $06^{0} 037^{1}$ to $06^{0} 949^{1} \mathrm{~N}$ and Longitude $10^{0} 018^{1}$ to $10^{0} 969^{1}$ with an altitude of between 903 to $1055 \mathrm{~m}$ a. s. 1. It is classified as a community forest. It has a mean annual precipitation of $2657.2 \mathrm{~mm}$, humidity of $80 \%$ and temperatures ranging from $22.3^{\circ} \mathrm{C}$ to $26.7^{\circ} \mathrm{C}$ with respect to rainy and dry seasons (Etia, 1980). Soils in Bafut are conditioned chiefly by topography and climate including alluvial soils, ferruginous soils and hydromorphic soils common in swampy valleys. There is unsustainable farming and timber exploitation activities going on in this forest and the need to control the exploitation of natural resources cannot be over overemphasized. The inhabitants of Bafut especially those beside the forest carryout activities in this forest such as farming, hunting, pruning of palms, palm oil production and gathering of medicinal plants. They also rely on this forest for fuel wood. There is a high way road passing through this forest to Menchum Division. The Bafut forest contributes significantly to the flow of the Menchum Fall as it acts as a catchment area. According to the North West Development Authority, the Bafut community receives value and benefits from this forest as they have access and right to the forest resources and participates in its management.

\subsection{Sample Collection and Preparation}

Four field surveys were conducted in the Bafut forest from the $6^{\text {th }}$ of April to the $25^{\text {th }}$ of April 2018 which was the fructification period for different types of polypores in the study area. A stratified random sampling method was used to map out transects in the forest. This method was used such that each position in the forest should have equal chance of being selected and it provides greater precision over simple random sampling method. The sampling was carried out in transects of $300 \mathrm{~m}$ by $10 \mathrm{~m}$, separated by a distance of $40 \mathrm{~m}$ between transects. A total of 10 transects were surveyed. Thorough search was applied and all the polypores present 
within each transect were collected. Each specimen within each transect was collected in separate specimen bags in order to avoid spore contamination among the different specimens. A total of 32 specimens were collected from their natural habitats with repetitions among transects. The macro morphological characteristics (cap length, colour, texture, moisture, description of surfaces) of the fruiting bodies were recorded and photographs taken in their natural habitats as these features might change with drying. Samples for molecular work were dried with silica gel granules and preserved in zip lock bags.

\subsection{DNA Extraction and PCR Amplification}

DNA was extracted from silica gel dried specimens of polypores using the CTAB (Cetyl Trimethyl Ammonium Bromide) extraction buffer method according to Moller et al. (1992). A piece of basidiocarp of each polypore was frozen separately in liquid nitrogen and lyophilized. $700 \mu \mathrm{l}$ of $\mathrm{CTAB}$ buffer was added to each sample tube containing the ground basidiocarp and incubated for $60 \mathrm{~min}$ at $68^{\circ} \mathrm{C}$. Samples were subsequently centrifuged for 5 min at $13000 \mathrm{rpm}$. The supernatant was transferred to fresh tubes and purified with $500 \mu 1$ chloroform: isoamyl alcohol (24:1) and precipitated with $500 \mu \mathrm{l}$ isopropanol, it was then centrifuged for $10 \mathrm{~min}$ at $13000 \mathrm{rpm}$. The supernatant was discarded and the pellets washed twice with $70 \%$ alcohol. DNA pellet was suspended in $30 \mu \mathrm{l}$ of $\mathrm{ddH}_{2} \mathrm{O}$ and DNA concentration and purity were determined by NanoDrop spectrophotometer (Thermo Scientific NanoDrop 2000) at absorbance (A260/280). The quality of DNA was visualized on a $1.5 \%$ agarose gel run at $7 \mathrm{~V} / \mathrm{cm}$ for $60 \mathrm{~min}$. The DNA was diluted to $40 \mathrm{ng} / \mu 1$ working stocks and stored at $4^{\circ} \mathrm{C}$ for further use.

\subsection{DNA Amplification and Purification}

Genomic DNA for all 15 samples was amplified by PCR using primers ITS 1 [5'TCCGTAGGTGAACCTGCGG-3'] and primer ITS4 [5'-TCCTCCGCTTATTGATATGC -3'] (White et al., 1990). This primer pair amplifies a phylogenetically informative portion of the ITS $1,5.8 \mathrm{~S}$ and ITS 2 gene regions. PCR amplification was done using a Biometra TRIO Analytic Jena thermocycler (Germany). PCR was premixed in a $25 \mu \mathrm{L}$ reaction volume containing $40 \mathrm{ng}$ template DNA, $0.18 \mu \mathrm{M}$ of each primer, $0.2 \mathrm{mM}$ of dNTPs, $0.4 \mu \mathrm{M}$ of each

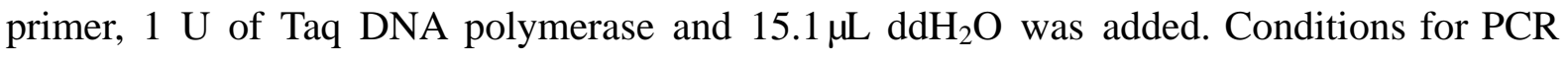
included 1 cycle of $30 \mathrm{~s}$ at $94{ }^{\circ} \mathrm{C}$; then 40 cycles of $30 \mathrm{~s}$ at $94{ }^{\circ} \mathrm{C}, 30 \mathrm{~s}$ at $58{ }^{\circ} \mathrm{C}$, and $6 \mathrm{~min}$ at 68 ${ }^{\circ} \mathrm{C}$; followed by 1 cycle of $5 \mathrm{~min}$ at $68{ }^{\circ} \mathrm{C}$ and a $4{ }^{\circ} \mathrm{C}$ soak. $5 \mu \mathrm{L}$ of each PCR product were electrophoretically separated on a $1 \%$ agarose gel prepared in $0.5 \mathrm{X}$ TAE to check the purity of the PCR product. The gel was run at $7 \mathrm{~V} / \mathrm{cm}$ for $45 \mathrm{~min}$. DNA staining was done with $0.025 \mathrm{X}$ ethidium bromide and photographed under UV exposure. Purification of PCR products was performed by ExoSAP using a Biometra TRIO Analytic Jena thermocycler (Germany). Sanger sequencing in both directions was conducted by Eurofins, USA with the same primers used for amplification.

\subsection{Phylogenetic Analysis}

Sequences obtained using ITS1 and ITS4 primers (White et al., 1990) were queried against known sequences in GenBank using BLASTn to determine their associated species identity. 


\section{Al Macrothink}

A phylogenetic analysis with MEGA version 7 (Kumar et al., 2016) was conducted for the one data set consisting of 12 sequences identified as polypores and 12 sequences which belonged to other polypores in the Genebank. A multiple sequence alignment was performed with MUSCLE using the default parameters (Edgar, 2004). The phylogenetic tree was constructed by Neighbor-joining method using the heuristic search option Tree-Bisection-Reconnection (TBR) branch swapping algorithm with 1000 random addition sequences with 1000 bootstrap replications. Unrooted ITS based phylogenetic trees were constructed to infer evolutionary relationships between isolates (Kinene et al., 2016).

\subsection{Ethnomycological Studies}

A total of 180 questionnaires were administered to four communities (45 in each community) around the Bafut forest. The communities were selected based on closeness to the forest and high population of the natives. The communities include; Bukari, Belingyie, Nchum and Buweh. The respondents included different age groups, sex, status, occupation and background. The age groups selected were; 14-24, 25-35, 36-46, 47-57, and >57 years. These age groups were selected based on the fact that, they visit the forest often, thus their familiarity with polypores in the forest and that individuals of different age group reason differently, thus variation in responses. Materials used to collect information from community members included; the specimens, pictures of the specimens and questionnaire. The questionnaire was constructed to obtain vital information including the name of the species, its uses, its ecology, habitat and relationship with other organisms.

\section{Results}

\subsection{DNA Amplification}

The length of the amplified product for all the polypores was between 600-700bp. From the sequences, ten polypores were identified with the aid of NCBI using BLAST and the results obtained are shown on Table 1 indicating high values for maximum identity and query coverage. 
Table 1. Polypores species identity using the ITS BLAST in NCBI

\begin{tabular}{|c|c|c|c|c|c|c|c|c|}
\hline $\begin{array}{l}\text { Sample } \\
\text { number }\end{array}$ & $\begin{array}{l}\text { GeneBank } \\
\text { number }\end{array}$ & Sequence ID & $\begin{array}{l}\text { Maximum } \\
\text { score }\end{array}$ & E-value & $\begin{array}{l}\text { Query } \\
\text { coverage(\%) }\end{array}$ & $\begin{array}{l}\text { Maximum } \\
\text { Identity(\%) }\end{array}$ & $\begin{array}{l}\text { Geographical } \\
\text { origin }\end{array}$ & Reference \\
\hline C9 & KT273357.1 & $\begin{array}{l}\text { Microporus } \\
\text { xanthopus }\end{array}$ & 1077 & 0.0 & 96 & 99 & Nigeria & $\begin{array}{l}\text { Adedokun et } \\
\text { al., } 2017\end{array}$ \\
\hline C36 & KP012981.1 & $\begin{array}{l}\text { Favolus } \\
\text { acervatus }\end{array}$ & 930 & 0.0 & 86 & 97 & China & Zhou, 2016 \\
\hline C43 & JN164981.1 & $\begin{array}{l}\text { Trametes } \\
\text { sanguinea }\end{array}$ & 1018 & 0.0 & 93 & 99 & USA & $\begin{array}{l}\text { Justo and } \\
\text { Hibbett, } 2011\end{array}$ \\
\hline $\mathrm{C} 48$ & КС589147.1 & $\begin{array}{l}\text { Trametes } \\
\text { hirsuta }\end{array}$ & 1070 & 0.0 & 99 & 99 & Cameroon & $\begin{array}{l}\text { Douanla-Meli } \\
\text { and Langer, } \\
2017\end{array}$ \\
\hline C68 & KY948738.1 & $\begin{array}{l}\text { Hexagonia } \\
\text { tenuis }\end{array}$ & 877 & 0.0 & 96 & 90 & unknown & $\begin{array}{l}\text { Justo et al., } \\
2017\end{array}$ \\
\hline C69BR & KM385427.1 & $\begin{array}{l}\text { Favolus } \\
\text { acervatus }\end{array}$ & 971 & 0.0 & 90 & 98 & China & $\begin{array}{l}\text { Zhou et al., } \\
2016\end{array}$ \\
\hline C69 & MH861473.1 & $\begin{array}{l}\text { Steccherinum } \\
\text { confragosum }\end{array}$ & 931 & 0.0 & 89 & 96 & unknown & $\begin{array}{l}\text { Vu et al., } \\
2018\end{array}$ \\
\hline C90 & AB509478.1 & $\begin{array}{l}\text { Cymatoderma } \\
\text { elegans }\end{array}$ & 993 & 0.0 & 98 & 94 & Japan & $\begin{array}{l}\text { Sato et al., } \\
2012\end{array}$ \\
\hline C104 & HM138672.1 & $\begin{array}{l}\text { Ganoderma } \\
\text { ryvardenii }\end{array}$ & 1104 & 0.0 & 99 & 99 & Cameroon & $\begin{array}{l}\text { Kinge and } \\
\text { Mih, 2011 }\end{array}$ \\
\hline $\mathrm{C} 112$ & LC176778.1 & $\begin{array}{l}\text { Microporus } \\
\text { xanthopus }\end{array}$ & 1036 & & 93 & 98 & Thailand & $\begin{array}{l}\text { Sitdhipol et } \\
\text { al., } 2016\end{array}$ \\
\hline $\mathrm{C} 122$ & KC589142.1 & $\begin{array}{l}\text { Trametes } \\
\text { elegans }\end{array}$ & 1054 & & 94 & 99 & Cameroon & $\begin{array}{l}\text { Douanla-Meli } \\
\text { and Langer, } \\
2017\end{array}$ \\
\hline TC9F & KP715551.1 & $\begin{array}{l}\text { Microporus } \\
\text { vernicipes }\end{array}$ & 1112 & 0.0 & 98 & 99 & Sri Lanka & $\begin{array}{l}\text { Ediriweera et } \\
\text { al., } 2015\end{array}$ \\
\hline
\end{tabular}

The 10 species of polypores identified was made up of four families consisting of seven Polyporaceae, one species each of Steccherinaceae, Meruliaceae and Ganodermataceae Table 2 and Figure 1.

Table 2. Families and species of identified polypore species by ITS

\begin{tabular}{lll}
\hline SN & Species & Family \\
\hline 1 & Microporus xanthopus (Fr.) Kuntze & Polyporaceae \\
2 & Microporus vernicipes (Berk.) Kuntze & Polyporaceae \\
3 & Favolus acervatus (Lloyd) Sotome \& T. Hatt & Polyporaceae \\
4 & Trametes sanguinea (L.)Imazeki & Polyporaceae \\
5 & Trametes hirsuta (Wulfen) Lloyd & Polyporaceae \\
6 & Trametes elegans (Spreng.) Fr. & Polyporaceae \\
7 & Hexagonia tenuis (Hook.) Fr. & Polyporaceae \\
8 & Steccherinum confragosum Maas Geest. \& Lanq. & Steccherinaceae \\
9 & Cymatoderma elegans. Jungh & Meruliaceae \\
10 & Ganoderma ryvardenii Kinge \& Mih & Ganodermataceae \\
\hline
\end{tabular}



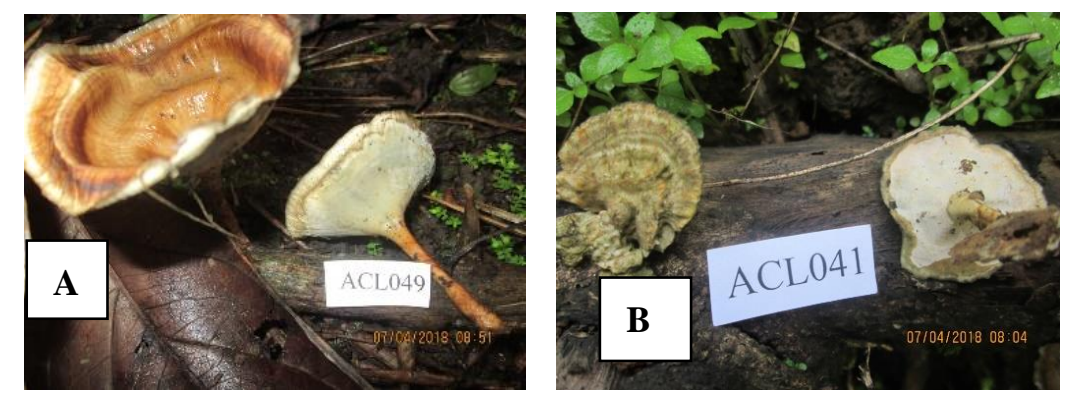
2019, Vol. 10, No. 2
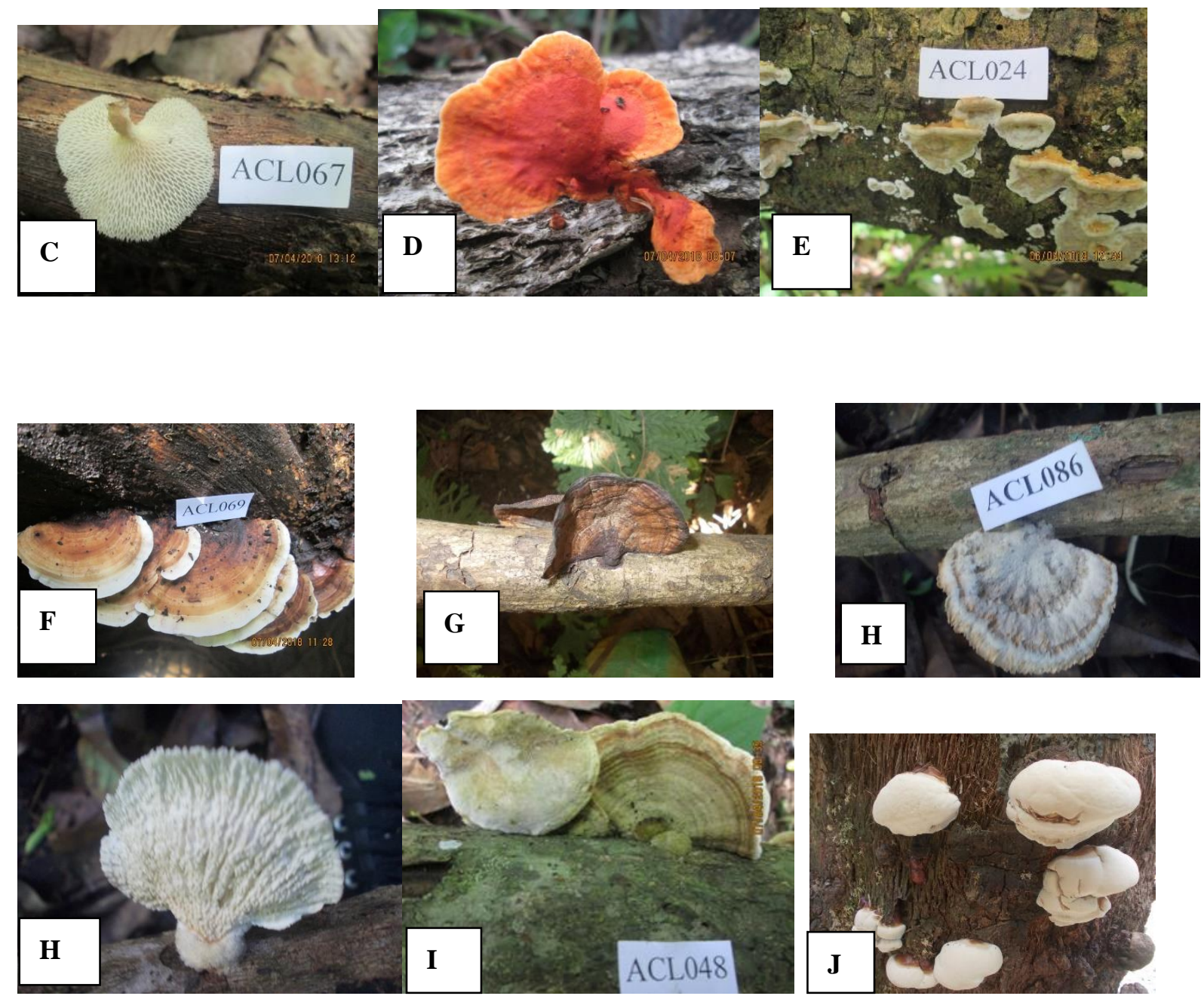

Figure 1. Some Polypores identified from the Bafut forest, Cameroon A) Microporus xanthopus B) Microporus vernicipes $\mathbf{C )}$ Favolus acervatus D) Trametes sanguinea $\mathbf{E}$ ) Trametes hirsuta $\mathbf{F})$ Trametes elegans G) Hexagonia tenuis $\mathbf{H})$ Cymatoderma elegans $\mathbf{I}$ Stecherinum confragosum $\mathbf{J}$ ) Ganoderma ryvardenii

\subsection{Phylogenetic Analysis}

The phylogenetic analysis produced a phylogram which resulted in 7 monophyletic groups. The phylogram consisted of samples collected from the study area together with those from GeneBank as shown in Figure 2. 


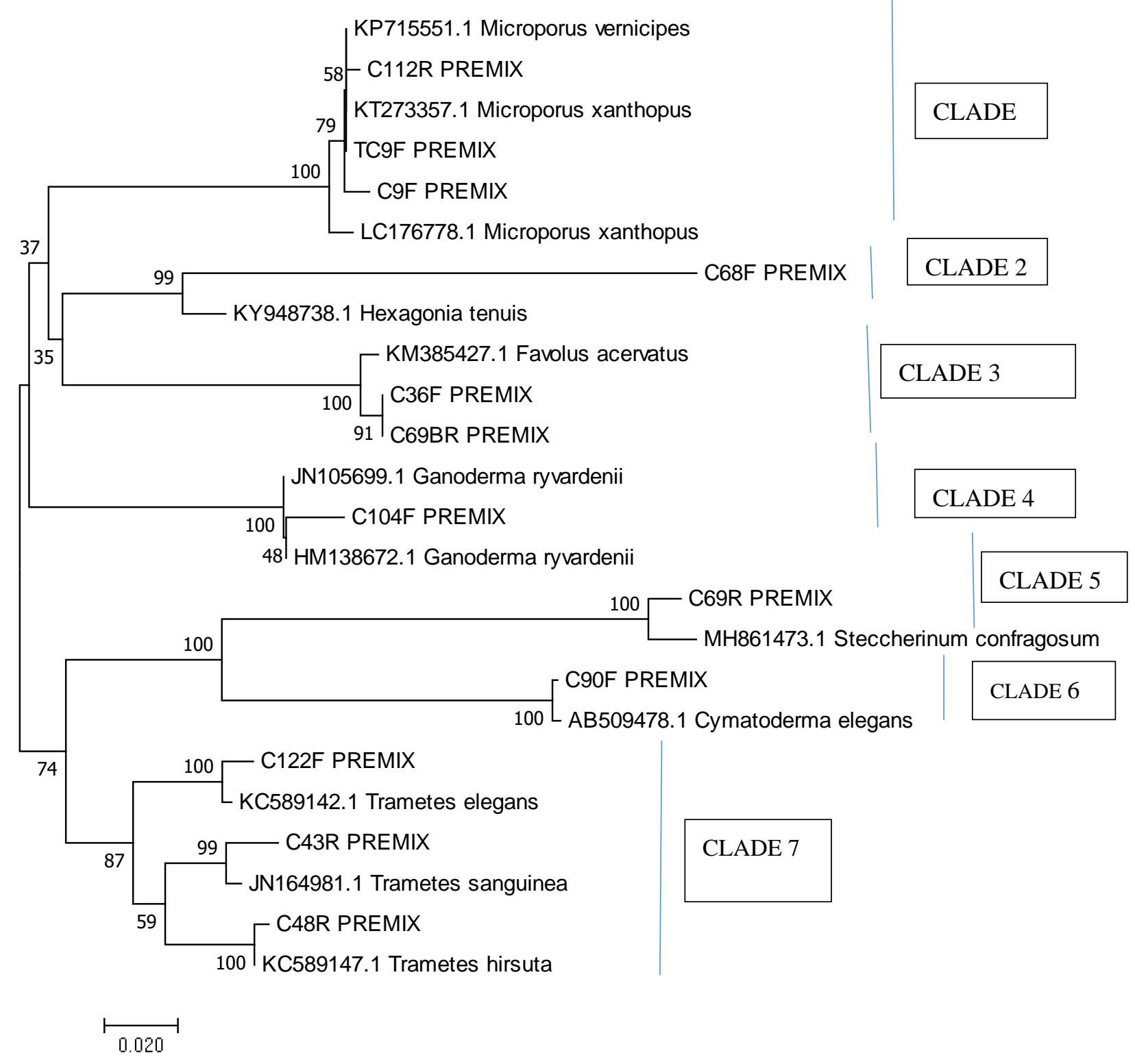

Figure 2. Unrooted Phylogenetic tree generated from ITS sequence data based on

Neighbor-joining analysis. Sample number is indicated at the node

\subsection{Ethnomycological Demographic Information of the Population}

Results from questionnaires revealed that, of the 180 respondents, $25.56 \%$ were between the ages of 14 and 24 years, $24.44 \%$ between 25 and 35 years, $27.22 \%$ between 36 and 46 years, $12.22 \%$ between 47 and 57 years and $10.56 \%$ of ages greater than 57 years. Females recorded $58.33 \%$ of the respondents and males $41.47 \%$. The occupation of the inhabitants was mainly farming (35\% of the respondents) (Table 3 ). 
Table 3. Demographic profiles of the surveyed communities in Bafut, North West Cameroon.

\begin{tabular}{|c|c|c|c|c|c|c|c|c|c|c|}
\hline \multirow[t]{2}{*}{ Communities } & \multirow{2}{*}{$\begin{array}{l}\text { Number of } \\
\text { respondents }\end{array}$} & \multicolumn{4}{|c|}{ Age group } & \multicolumn{3}{|c|}{ Gender } & \multicolumn{2}{|c|}{ Occupation } \\
\hline & & 14-24 & $25-35$ & $36-46$ & $47-57$ & $>57$ & Male & Female & Farmer & Others \\
\hline Bukari & 45 & 17 & 10 & 9 & 6 & 3 & 17 & 28 & 14 & 31 \\
\hline Buweh & 45 & 6 & 11 & 17 & 6 & 5 & 16 & 29 & 19 & 26 \\
\hline Belingyie & 45 & 10 & 12 & 11 & 5 & 7 & 19 & 26 & 19 & 26 \\
\hline Nchum & 45 & 13 & 11 & 12 & 5 & 4 & 23 & 22 & 11 & 34 \\
\hline Total & 180 & 46 & 44 & 49 & 22 & 19 & 75 & 105 & 63 & 117 \\
\hline
\end{tabular}

\subsection{Ethnomycological Knowledge of Polypores}

Information from this survey revealed that the inhabitants of Bafut have a positive affection towards polypores. $76.11 \%$ of the respondents reported polypores as food, while $11.11 \%$ of the respondents added that polypores were also used to treat various ailments. $3.89 \%$ of the respondents reported both edible and medicinal polypores. $8.89 \%$ of the respondents disliked mushrooms in general and did not provide any information about its use. The indigenes of Bafut had one way by which they determined edibility of mushroom species. They could only determine edibility based on the knowledge from their parents who told them that a particular mushroom is edible and others are not edible. That is the knowledge on edibility was handed down from parents to children, orally. Some respondents had different views to the uses of polypores (Table 4).

Table 4. Number of respondents with different views to the uses polypores

\begin{tabular}{lllll}
\hline Communities & Edible & Medicinal & Edible/Medicinal & Dislike \\
\hline Bukari & 35 & 5 & 2 & 4 \\
Buweh & 35 & 4 & 1 & 4 \\
Belingyie & 36 & 5 & 3 & 5 \\
Nchum & 31 & 6 & 1 & 3 \\
\hline Total & 137 & 20 & 7 & 16 \\
\hline
\end{tabular}

Microporus xanthopus and Microporus vernicipes were recorded as both edible and medicinal. Trametes was reported to be used only in medicine. The indigenes reported that, the medicinal polypore Trametes elegans is prepared by roasting together with corn cobs to arches. The arches are then mixed with palm oil and licked against stomach pain, cough and sour throat. Another medicinal species, Trametes hirsuta is burned to arches and mixed with palm oil against skin fungi and herpes zoster. Other species such as Ganoderma ryvardenii was reported to be medicinal, when mixed together with some plant species to treat heart diseases. 


\section{Discussion}

The present study shows the efficiency of ITS region to differentiate various species of polypores. Twelve specimens of polypores were amplified using the ITS gene region resulting in the identification of ten species of polypores. These species include; Microporus xanthopus, Microporus vernicipes, Favolus acervatus, Trametes sanguinea, Trametes hirsuta, Trametes elegans Hexagonia tenuis, Steccherinum confragosum, Cymatoderma elegans and Ganoderma ryvardenii. Phylogenetically, Microporus xanthopus and Microporus vernicipes formed a monophyletic group. These species have been reported from Cameroon by Douanla-Meli (2007), from the Mbalmayo Forest Reserve. Microporus xanthopus is phylogenetically related to species from Nigeria and Thailand. Microporus vernicipes is related to species from Sri Lanka. The clade had a significant support of 100\%. Microporus xanthopus had been revised by Kuntze (1898) to Polyporus xanthopus with its species being paraphyletic to the rest of the Polyporaceae members. These species share common features such as thin funnel shaped fruiting body, various wavy shades concentrically zoned, lower surface with lots of micropore and diameter of 7.2 to $10.1 \mathrm{~cm}$ (Zhishu et al., 1993). Microporus vernicipes and Trametes hirsuta found in this study were related morphologically to species from Japan previously reported by Hattori (2005) who worked on the diversity of wood-inhabiting polypores in temperate forests with different vegetation types. Hexagonia tenuis was related to a species from an unknown location and formed a sister group to Favolus acervatus which is related to species from China. Hexagonia tenuis had previously been reported from Cameroon by Douanla-Meli, (2007) from the Mbalmayo Forest Reserve. The clade for Ganoderma ryvardenii was strongly supported (100\%). This species was found on dead wood tree in the Bafut forest. However, Ganoderma ryvardenii had previously been described as a new species in oil palm plantation in south western Cameroon and from deadwood in Idenau, Bueatowm and Ekona in the mount Cameroon Region by Kinge and Mih (2011) and was also reported by Kinge et al. (2013) in the first checklist of macrofungi of mount Cameroon. Hence a new location for Ganoderma ryvardenii has been discovered in this study.

Molecular phylogenetic studies revealed that, Cymatoderma is polyphyletic with species grouped together in the polyporales clade (Sjokvist et al., 2012). Cymatoderma elegans was phylogenetically related to species from Japan. Steccherinum confragosum was related to species from an unknown locality. Steccherinum confragosum formed a sister group to Cymatoderma elegans and the grouping was strongly supported (100\%). The phylogenetic analysis of the Polyporaceae revealed a close relationship between Trametes sanguinea, Trametes hirsuta and Trametes elegans with a support of $88 \%$. Some of the species collected from the Bafut forest have been reported in other regions of Cameroon. For example, Trametes elegans and Trametes hisurta were evolutionary related to species from Cameroon previously reported by Douanla-Meli (2007) from the Mbalmayo Forest Reserve, Trametes elegans had been reported by Kinge et al. (2013) in the Mount Cameroon Region specifically in the localities of Idenau, Bafia and Ekona. Trametes sanguinea and Trametes hirsuta found in this study had been reported by Teke et al. (2017) on macro fungal diversity in the Kilum-Ijim forest, Cameroon. In this study Trametes sanguinea was related to species from U.S.A. Favolus acervatus was related to species from China. Species of Favolus and 


\section{Macrothink}

Trametes have been reported to be polyphyletic. This is supported by the fact that, in early classification, Beauvois concept of Favolus is placed in synonym with Trametes and Favolus hirtus, is now called Trametes hirta (www.indexfungorum.org). Recently, many works have considered Favolus to be synonymous with Polyporus and several species of Favolus were transferred to Neofavolus (Sotome, 2013). This reorganization was accepted and verified in later studies (Dai et al., 2014; Seelan et al., 2015 \& Zmitrovich et al., 2016).

Inhabitants of Bafut consume edible polypores because of oral tradition that is, their parents told them to eat a particular mushroom and not others. The people commonly call mushrooms "Boh" and those that grow on wood "Boh ti". They usually differentiate the edible and nonedible mushrooms using the term "yi kworu" and "yi tekworu". Thus "Boh yi kworu" and "Boh yi tekworu" respectively. The indigenes reported that, they usually collect edible species of polypore and other mushrooms during the rainy season in abundance, eat some and also sell the remains in local markets. They collect edible polypore in this forest while doing other activities such as farming, hunting and oil palm cultivation. The study has proven polypores as important mushrooms in the forest which are exposed to several threats yet very vital to the inhabitants in communities of the Bafut forest. It was found that, most of the respondents who were farmers gathering these polypores were females. Thus females play an important role in the traditional knowledge of polypores in the Bafut forest. This corroborates with the findings of Tonjock et al. (2017) on species richness and traditional knowledge of macrofungi (Mushrooms) in the Awing forest reserve and communities, northwest region of Cameroon and Akpaja et al. (2003) on ethnomycology and usage of edible and medicinal mushrooms among the Igbo people of Nigeria. Some of the species of polypores were reported to be edible; for example, Laetiporus sulphureus. This species was identified only by morphology as it is relatively easy to identify. This species was also reported to be edible by Teke et al. (2018) on ethnomycological study in the Kilum-Ijim mountain forest, North West region of Cameroon. Species from the genus Microporus, Trametes and Ganoderma have also been reported to be medicinal by other authors in different ethnomycological studies.

\section{Conclusions}

Ten species of the polyporales were identified in this study using molecular methods as belonging to seven genera comprising of the Microporus, Hexagonia, Ganoderma, Trametes, Favolus, Steccherinum and Cymatoderma which formed 7 independent monophyletic groups. Ethnomycological findings revealed that, polypores are used as food and medicine within the communities of the Bafut forest reserve. This is the first study to report on the identification, phylogenetic relationship of polypores from the Bafut forest using the ITS gene region and also document the uses of polypores as food and medicine to the communities around the Bafut forest. The result obtained is important for the conservation of polypores in the study area since they are threatened by anthropogenic factors such as deforestation and logging.

\section{Acknowledgements}

The authors acknowledge the assistance of the University of Bamenda, Cameroon for providing material resources and all the field assistants who helped during fieldwork. Authors kindly thank Idea Wild for their support with technical equipment. 


\section{References}

Aandra, R., Rolstad, J., \& Songen S. M. (1996). Biological diversity in forests. Norges skogeirforbund og A/S Landbruksforlaget, 46.

Alexopoulos, C. J., Mims, C. W., \& Blackwell, M. (1996). Introductory Mycology (4th ed.). New York: John Wiley \& Sons, Inc.

Akpaja, E. O., Isikhuemhen, O. S., \& John, O. A. (2003). Ethnomycology aand Usage of Edible and Medicinal Mushrooms among the Igbo People of Nigeria. International Journal of Medicinal Mushrooms, 5(3), 312-319. https://doi.org/10.1615/InterJMedicMush.v5.i3.100

Barbosa-Filho, J. M., Piuvezam, M. R., Moura, M. D., Silva, M. S., \& Lima, K. V. B. (2006). Anti-inflammatory activity of alkaloids: A twenty- century review. Rev. Brasileira de Farmacognosia, 16, 109-139. https://doi.org/10.1590/S0102-695X2006000100020

Chang, S. T. (1996). Mushroom biology: the impact on mushroom production and mushroom products. In: Royse, J. (Ed.). Proceedings of the 2nd International Conference on Mushroom Biology and Mushroom Products. University Park, Pennsylvania, USA. pp. 3-20.

Chen, H., Ju, Y., Li, J., \& Yu, M. (2012). Antioxidant activities of Polysaccharides from Lentinus edodes and their significance for disease prevention. International Journal of Biological Macromolecules, 50(1), 214-218. https://doi.org/10.1016/j.ijbiomac.2011.10.027

Dai, Y. C., Xue, H. J., Vlasak, J., Rajchenburg, M., Wang, B., \& Zhou, L. W. (2014). "Phylogeny and Global diversity of Polyporus group Melanopus (Polyporales, Basidiomycota)". Fungal Diversity, 64(1), 133-144.

https://doi.org/10.1007/s13225-013-0248-3

Douanla-Meli, C. (2007). Fungi of Cameroon, Ecological Diversity; Taxonomy of Non-gilled Hymenomycetes, Mbalmayo Forest Reserve.Bibliotheca Mycologica 410P

Edgar, R. C. (2004). MUSCLE: multiple sequence alignment with high accuracy and high throughput. Nucleic Acids Research, 32, 1792-1797. https://doi.org/10.1093/nar/gkh340

Etia, P. M. (1980). Climate and climatic zones of Cameroon. In: J.A, Editor. Les Atlas Jeune Afrique: Paris, France.

Fasidi, I. O., \& Kadiri, M. (1990). Changes in nutrient contents of two Nigerian mushrooms, Termitomyces robustus (Beeli) R. Heim and Lentinus subnudus Berk during sporophore development. Die Nährung, 34, 415-420. https://doi.org/10.1002/food.19900340504

Gottlieb, A. M., \& Wright, J. E. (1999). Taxonomy of Ganoderma from southern South America: subgenus Ganoderma. Mycological Research, 103(6), 661-673. https://doi.org/10.1017/S0953756298007941

Guarro, J., Gené, J., \& Stchigel, A. M. (1999). Developments in fungal taxonomy. Clinical Microbiology Reviews, 12, 454-500. https://doi.org/10.1128/CMR.12.3.454 
Hattori, T. (2005). Diversity of wood-inhabiting polypores in temperate forest with different vegetation types in Japan. Fungal Diversity, 18, 73-88.

Hibbett, D. S., \& Donoghue, M. J. (1995). Progress toward a phylogenetic classification of the Polyporaceae through parsimony analysis of mitochondrial ribosomal DNA sequences. Canadian Journal of Botany, 73, 853-861. https://doi.org/10.1139/b95-331

Hibbett, D. S., Binder, M., Bischoff, J. F., Blackwell, M., Cannon, P. F., Eriksson, O. E., \& Zhang, N. (2007). A higher-level phylogenetic classification of the Fungi. Mycological Research, 111, 509-547. https://doi.org/10.1016/j.mycres.2007.03.004

Jia, J., Zhang, X., \& Hu, Y. S. (2009). Evaluation of in vivo antioxidant Activities of Ganoderma lucidum polysaccharides in STZ-diabetic rats. Food Chemistry, 115, 32-36. https://doi.org/10.1016/j.foodchem.2008.11.043

Kadiri, M. (2005). Toxicological evaluation of Lentinus squarrosulus Mont. (Polyporales), an indigenous Nigerian mushroom. International Journal of Medicinal Mushrooms, 7(3), 416-417. https://doi.org/10.1615/IntJMedMushr.v7.i3.590

Kinene, T., Wainaina, J., Maina, S., \& Boykin, L. M. (2016). "Rooting Trees, Method for," in Encyclopedia of Evolutionary Biology, ed. R. M. Kliman (Oxford: Academic Press), 489-493. https://doi.org/10.1016/B978-0-12-800049-6.00215-8

Kinge, T. R., \& Mih. A. M. (2011). Ganoderma ryvardenii sp. nov. Associated with Basal Stem Rot disease of oil palm in Cameroon. Mycosphere, 2(2), 179-188.

Kinge, T. R., Egbe, E. A., Tambi, E. M., Nji, T. M., \& Mih, A. M. (2013). The First check list of macrofungi of mount Cameroon. Mycosphere, 4(4), 694-699. https://doi.org/10.5943/mycosphere/4/4/5

Kinge, T. R., \& Mih, A. M. (2015). Diversity and distribution of species of Ganoderma in South western Cameroon. Journal of Yeast and Fungal Research, 6(2), 17-24. https://doi.org/10.5897/JYFR2014.0150

Kirk, P. M., Cannon, P. F., Minter, D. W., \& Stalpers, J. A. (2008). Dictionary of the Fungi (10 ${ }^{\text {th }}$ Ed.). Wallingford Oxon, UK, 771.

Kumar, S., Stecher, G., \& Tamura, K. (2016). MEGA7: Molecular Evolutionary Genetics Analysis version 7.0 for bigger datasets. Molecular Biology and Evolution, 33, 1870-1874. https://doi.org/10.1093/molbev/msw054

Kuntze (1898). Revisio generum plantarum, 3(2), 494.

Li, H. J., \& Cui, B. K. (2013). Taxonomy and phylogeny of the genus Meagasporoporia and its related genera. Mycologia, 105, 368-383.

Moller, E. M., Bahnweg, G., Sandermann, H., \& Geiger, H. H. (1992). A simple and efficient protocol for isolation of high molecular weight DNA from filamentous fungi, fruit bodies, and infected plant tissues. Nucleic Acids Research, 22, 6115-6116. https://doi.org/10.1093/nar/20.22.6115 
Moncalvo, J. M., \& Ryvarden, L. (1997). A nomenclatural study of the Ganodermataceae Donk. Fungiflora; Oslo, 1-114pp.

Mueller, G. M., Schmit, J. P., Leacock, P. R., Buyck, B., Cifuentes, J., Desjardin, D. E., \& Wu, W. (2007). Global diversity and distribution of macrofungi. Biodiversity Conservation, 16, 37-48. https://doi.org/10.1007/s10531-006-9108-8

Nakasone, K. K. (2013). Taxonomy of Epithele (Polyporales, Basidiomycota). Sydowia, 65(1), 59-112.

Nunez, M., \& Daniels, P. P. (1999). Fungi from the Dja Biosphere Reserve (Cameroon) 11. Polypores. Mycotaxon, 13, 235-246.

Osemwegie, O. O., Eriyaremu, E. G., \& Abdulmalik, J. (2006). A survey of macrofungi in Edo/Delta region of Nigeria, their morphology and uses. Global Journal of Pure and Applied Science, 12(2), 149-157. https://doi.org/10.4314/gjpas.v12i2.16583.

Roberts, P., \& Ryvarden, L. (2006). Poroid fungi from Korup National Park, Cameroon. Kew Bulletin, 55-78.

Ryvarden, L. (1991). Genera of polypores, nomenclature and taxonomy. Synopsis Fungorum. $5,1-373$.

Seelan, J. S. S., Justo, A., Nagy, L. G., Grand, E. A., Redhead, S. A., \& Hibbett, D. (2015). "Phylogenetic relationship and morphological evolution in Lentinus, Polyporellus and Neofavolus, emphasizing Southeastern Asian taxa". Mycologia, 107(3), 460-474. https://doi.org/10.3852/14-084

Sjokvist, E., Larrson, E., Eberhardt, U., Ryvarden, L., \& Larsson, K. H. (2012). Stipitate Steroid Basidiocarps have evolved multiple times. Mycologia, 104, 1046-1055. https://doi.org/10.3852/11-174

Sotome, K., Akagi, Y., Lee, S. S., Ishikawa, N. K., \& Hattori, T. (2013). Taxonomic study of Favolus gen. nov. Segregated from Polyporus (Basidiomycota, Polyporales). International Journal of Mycology, 58 (1), 245-266. https://doi.org/10.1007/s13225-012-0213-6

Teke, N. A., Kinge, T. R., Bechem, E., Mih, A. M., Kyalo, M., \& Stemeo, F. (2017). Macro-Fungal Diversity in the Kilum-Ijim Forest, Cameroon. Studies in Fungi, 2(1), 47-58. https://doi.org/10.5943/sif/2/1/6

Teke, N. A., Kinge, T. R., Bechem, E., Nji, T. M., Ndam, L. M., \& Mih, A. M. (2018). Ethnomycological study in the Kilum-Ijim mountain forest, Northwest Region, Cameroon. Journal of Ethnobiology and Ethnomedicine, 14(25).

https://doi.org/10.1186/s13002-018-0225-8

Tonjock, R. K., Nkengmo, A. A., Nji, T.M., Ache, N.A., \& Mih, A. M. (2017). Species Richness and Traditional Knowledge of Macrofungi (Mushrooms) in the Awing Forest Reserve and Communities, Northwest Region, Cameroon. Journal of Mycology, https://doi.org/10.1155/2017/2809239. 


\section{Macrothink}

Wachtel, G. S., Yuen, J., Buswell, J. A., \& Benzie, I. F. F. (2011). Ganoderma lucidum (Lingzhi or Reishi): A Medicinal Mushroom. In: Benzie, I.F.F. and Wachtel-Galor S. editors. Herbal Medicine: Biomolecular and Clinical Aspects. 2nd edition. Boca Raton (FL): CRC Press. PP 48.

White, T. J., Bruns, T., Lee, S., \& Taylor, J. (1990). Analysis of phylogenetic relationships by amplification and direct sequencing of ribosomal RNA genes. In PCR Protocols: A Guide to Methods and Applications. Innis, MA, Gelf and DH, Sninsky JJ, White TJ, eds. New York, Academic Press.

Zhishu, B., Zheng, G., \& Taihui, L. (1993). The Macro Fungus Flora of China's Guangdong Province. The Chinese University Press. Pp756. ISBN 978-962-201-556-2.

Zmitrovich, I. V., \& Kovalenko, A. E. (2016). Lentinoid and Polyporoid Fungi, two generic conglomerates containing important medicinal mushrooms in molecular perspective. International Journal of Medicinal Mushrooms, 18(1), 23-38.

https://doi.org/10.1615/IntJMedMushrooms.v18.i1.40

\section{Copyright Disclaimer}

Copyright for this article is retained by the author(s), with first publication rights granted to the journal.

This is an open-access article distributed under the terms and conditions of the Creative Commons Attribution license (http://creativecommons.org/licenses/by/3.0/). 